\title{
Családok szülésre és szülőségre való felkészítése - változások az előző generációhoz képest
}

\section{Preparing families for birth and parenthood - changes compared to the previous generation}

\author{
Szerzők: Soósné Dr. Kiss Zsuzsanna ${ }^{a} \bowtie$, Péter Melindaa, Lipienné Dr. Krémer Ibolyab \\ a: Semmelweis Egyetem, Egészségtudományi Kar, Egészségtudományi Klinikai Tanszék, Budapest, \\ b: Semmelweis Egyetem, Egészségtudományi Kar, Szülészeti és Nőgyógyászati Klinikai Ismeretek \\ Tanszék, Budapest
}

Beküldve: 2018. 06. 11.

doi: 10.24365/ef.v59i5.329

\begin{abstract}
Bevezetés: A szülés, szülővé válás az egyének és családok kiemelkedően fontos, örök és folyamatosan változó életeseménye, amely generációról generációra új kihívások elé állítja a családokkal foglalkozó szakembereket.

Célkitűzés: Tanulmányunk célja az előző generációhoz képest történő változások, a modern szemléletű szülésre és szülőségre felkészítés bemutatása szakirodalmi kutatómunka és saját szakmai tapasztalatok alapján. Célunk vizsgálni a változásokat (1) a családtípusok átalakulása, a család múködéséről alkotott felfogások és szülői feladatok, (2) a szüléssel és szüléstámogatással kapcsolatos modern szemléletmód, (3) a szakmai támogatás rendszere vonatkozásában.

Eredmények: (1) A családtípusok átalakultak (házasságba, élettársi kapcsolatba, egyszülősés mozaikcsaládba egyaránt születő gyermekek). Kialakult a családok múködésmódjával (rendszerszemlélet), és a szülői feladatokkal (családi életciklus mentén történő gondolkodás a szülői feladatokról) kapcsolatosan egy új szemléletmód. (2) A szülési félelmet és fájdalmat enyhítő, szüléstámogató, nő- és családcentrikus szülészeti szemlélet (a szülés egy természetes folyamat, a külső fizikai környezet és szüléskísérői támogatás szerepe fontossá vált) és gyakorlat alakult ki.

(3) A szakmai munkára vonatkozó új jogszabályok születtek. A szakmai támogatás rendszere (gondozás, csoportos felkészítés, önálló tanulás erősítése) mennyiségi (új szakmák megjelenése) és minőségi változáson ment keresztül.
\end{abstract}

Következtetések: Mindhárom vizsgált területen jelentős változások történtek az előző generációhoz képest. Az eredményes felkészítés érdekében javasoljuk a szakmai munka általunk is vizsgált hármas szempontrendszere - (1) család és szülőség, (2) szülés és szüléstámogatás, (3) szakmai támogatás rendszere - szerinti folyamatos felülvizsgálatot.

Kulcsszavak: szülés; szülőség; család; szülésre felkészítés; szakmai támogatás

Introduction: Childbirth and becoming a parent is of crucial importance to families and individuals. This eternal and ever-changing life event challenges the family-specialized professionals across generations.

Aims: The goal of this study was to examine changes compared to the previous generation focusing on the approach to preparation for birth and parenthood, based on literature research and own professional experience. Furthermore, we examined changes (1) in the transformation of family types, the perceptions of family functioning and parental responsibilities, (2) the modern approach to childbirth and maternity support, (3) and the system of professional support.

Results: (1) Family models have transformed so that either married couples, life partners, single-parents or blended families bring up children. A novel approach has been developed in the way how families work (i.e. system approach) and parental responsibilities (i.e. thinking about family life cycle as regards parental responsibilities). (2) Supporting practices have emerged 
to reduce fear of childbirth and pain. Nowadays, childbirth is considered as a natural process, and the external physical environment as well as the childbearing support role has become important. Family-oriented obstetric attitudes and practices have improved. (3) New legislation on professional work has been created. The system of professional support (e.g. care, group preparation, and self-improvement) has undergone quantitative (i.e. new professions) and qualitative changes.

Conclusions: Significant changes have happened in all three examined areas compared to the previous generation. Recent changes suggest that performing a continuous review of all three examined aspects can contribute to a successful preparation.

Keywords: childbirth; parenting, family; childbirth education; professional support

\section{BEVEZETÉS}

A szülés, szülővé válás az egyének és családok kiemelkedően fontos, örök és folyamatosan változó életeseménye, amely generációról generációra új kihívások elé állítja a szakembereket. A téma az egyének, a családok és a társadalom szempontjából rendkívül jelentős. Úgy gondoljuk, hogy a múlt és jelen kutatása, a tapasztalatok átgondolása a jövőre vonatkozóan hasznosak lehetnek a családok egészségfejlesztésével foglalkozó szakemberek számára.

Tanulmányunk célja az előző generációhoz képest történő változások, a modern szemléletű szülésre és szülőségre felkészítés bemutatása szakirodalmi kutatómunka és saját szakmai tapasztalatok alapján. Célunk vizsgálni a változásokat (1) a családtípusok átalakulása, a család múködéséről alkotott felfogások és szülói feladatok, (2) a szüléssel és szüléstámogatással kapcsolatos modern szemléletmód, (3) a szakmai támogatás rendszere vonatkozásában.

\section{CSALÁDTÍPUSOK ÁTALAKULÁSA, A CSALÁD MŰ- KÖDÉSÉRŐ́L ALKOTOTT FELFOGÁSOK VÁLTOZÁSA, SZÜLŐI FELADATOK}

Napjainkra - az előző generáció gyermeket vállaló párjaihoz képest - jelentősen megváltoztak a családi együttélési formák, jellemzően nukleáris, kétgenerációs családban élnek a családok, kevés a háromgenerációs család. Kevesebb újszülött érkezik házasságba, és egyre magasabb számban élettársi kapcsolatba, egyszülős- vagy mozaikcsaládba is születnek a gyermekek. Az első gyermek vállalásának átlagos ideje a 28-30 éves életkorra tolódik, az anyák és az apák is idősebbek a gyermekek születésekor. A családról már rendszerszemlélettel gondolkodunk. Az első, és minden egyes gyermek megszületésekor a családi rendszer mennyiségileg és minőségileg is átalakul. Az első gyermek fogantatása, megszületése jelenti talán a legnagyobb változást a családban, mert a pár ekkor indul el a szülővé válás útján. A gyermekvárás-születés idejét az első családi életszakasznak tartjuk, fészekrakásnak, gyermeket váró- és újszülöttet nevelő család életciklusnak nevezzük, és normatív krízisként definiáljuk. Ebbe az életciklusba lépve indul el az új család élete. Tudjuk, hogy számos új feladattal kell ilyenkor megbirkóznia a családnak, a férfinak és nőnek már nemcsak párként, hanem szülőként is múködnie kell, ami nem minden családnak sikerül. ${ }^{1,2,3,4,5} \mathrm{~A}$ családalapítás nehézségeinek okai hat csoportba sorolhatóak: család strukturális felépítésének és a helyzeteknek-szerepeknekkapcsolatoknak a változása; a családi fejlődés természetes és váratlan eseményei; új, megoldásra váró feladatok; gyermekneveléssel kapcsolatos felfogások és alkalmazott pedagógiai módszerek; generációk közötti kapcsolat és konfliktushelyzetek. ${ }^{6} \mathrm{Az}$ első gyermeket váró családok körében végzett kutatás szerint az új családra vonatkozó együttélési keretek tisztázottsága leginkább a mindennapi életben nem olyan nagy jelentőséggel bíró ünnepekre, a pár-, és saját szülőkkel való kapcsolatra, az értékrendre, valamint az egymással szembeni elvárásokra igaz. A napi élet szempontjából lényeges tényezők, mint például a mindennapi együttélés szabályai, az egyezségek, a feladatok megosztása, a célok, szokások tisztázottságára vonatkozóan valamivel nagyobb bizonytalanság tapasztalható. A szülőségre vonatkozó legfontosabb keretek közül leginkább az értékeket, ünnepeket, 
célokat, a saját szülővel való együttmúködést, és a szülői elvárásokat gondolják tisztázottnak a szülők. A mindennapi élet szempontjából fontosabb szabályok, szokások, gyermeknevelési elvek, egyezségek, valamint a pár szüleivel való együttmüködés tisztázottsága kevésbé jellemző. Mindezek a sikeres családdá szerveződést nehezítő tényezők. ${ }^{4}$

$\mathrm{Az}$ 1997-ben megjelent gyermekvédelmi törvényünkben definiálásra kerültek a gyermekek jogai és kötelezettségei, a szúlöi jogok és kötelezettségek. ${ }^{7}$ Eszerint minden gyermeknek joga van a testi, értelmi, érzelmi és erkölcsi fejlődését, jólétét biztosító saját családi környezetében történő nevelkedéshez, a fejlődésére ártalmas környezeti és társadalmi hatásoktól, egészségére káros szerektől való védelemhez. Joga van emberi méltósága tiszteletben tartásához, a bántalmazással - fizikai, szexuális vagy lelki erőszakkal -, az elhanyagolással szembeni védelemhez is. A szülők kötelezettsége, feladata a fentiek biztosítása, ugyanakkor joguk is van ahhoz, hogy gyermekük gondozásáhozneveléséhez szükséges segítséget kapjanak a szakemberektől. ${ }^{7}$

Szakmai tapasztalataink alapján nem minden szülő van tisztában a már több mint 20 éve megjelent gyermekvédelmi törvényben foglalt szülői kötelezettségekkel és jogokkal.

\section{A SZÜLÉSSEL ÉS SZÜLÉSTÁMOGATÁSSAL KAPCSOLATOS SZEMLÉLETMÓD VÁLTOZÁSA}

A szülés eredetileg természetes folyamat volt, természetes közegben zajlott, később a szülések átkerültek a kórházakba. Napjainkban a szülések zöme még mindig kórházakban zajlik.

A modern szüléssel, szülés-, és szülőtámogatással kapcsolatosan a 90'-es évek közepén fogalmazódtak meg - a napjainkig is érvényes - a pozitív változás szempontjából jelentős ajánlások, mint például az, hogy a szülés egy természetes folyamat, a vajúdás és szülés során a lehető legkevesebb külső beavatkozást tegyék a szakemberek. Biztosítani kell a szülő nő számára a vajúdás és szülés alatt a meghitt környezetet, részére megfelelő érzelmi és társas támogatást kell nyújtani. ${ }^{8,9}$ Hazánkban az 1990-es évek közepén jelentek meg először olyan könyvek ${ }^{10,11}$, amelyek a kórházi körülmények között történő szüléseknél is a szülés-születés természetességére, a külső, szülészeti beavatkozások lehetséges elkerülésére, a háborítatlan, gyöngéd születésre, az újszülött érző, érzékeny személyiségére, és a fizikai és társas környezet fontosságára hívták fel a szakemberek, és a szülók figyelmét. A szerzők tudatosítják, hogy a fájdalom a szülési folyamat természetes része, ennek elfogadása, követése, a szülés alatti anyai természetes viselkedés alapvetően fontos a szülési fájdalommal történő megküzdés során. Felhívják a figyelmet arra, hogy a környezeti miliőnek, többek között a hangoknak (csend, suttogás, halk zene), a fénynek (vakító fények mellőzése, természetesen beszűrődő fény, besötétített szoba), a testi kontaktusnak (lágy érintés, simogatás, bőr-bőr kontaktus), a társ (elsősorban az édesapa) jelenlétének, az intim pillanatoknak, a szakemberek segítő jelenlétének, elérhetőségének, a szüléstől való félelem és a szülési fájdalom csökkentésében, a pozitív szülési élmények, és a kedvező anya-újszülött kapcsolat kialakulásában, valamint a családdá szerveződésben óriási szerepe van. ${ }^{10,11}$

A '90-es évek első éveitől a „Család-barát szülészet” program a vajúdás eltérő formáit, a szülés alternatív lehetőségeit, a vízszintes (horizontális/hagyományos/fekvő) szülési helyzet mellett a különféle függőleges (vertikális, guggoló, ülő, félig ülő stb.) szülési lehetőségeket, szülést megkönnyítő eszközöket (zuhany, kád, óriáslabda), az apával történő együttszülést ajánlotta a szülő nőknek. Hazánkban a családbarát-szülészet szemlélettel kapcsolatosan először napvilágot látott könyv a szülés helyének a kórházat ajánlja, amely az otthonias körülményekhez hasonló környezetet biztosít, a szülő nő kontrollált szakmai körülmények közötti, sikeres szülését biztosítja, és szükség esetén a szülő nő, a magzat, és az újszülött egészsége és biztonsága érdekében gyors szakorvosi beavatkozást tesz lehetővé. ${ }^{12}$ A családbarát szülészetet jellemzi az otthonosan kialakított, kényelmes, nyugalmat árasztó szülőszoba, a szülőkádban, vízben történő vajúdás melynek fájdalomcsökkentő hatása van -, a szabad hely-, és helyzetváltoztatás, a privát szféra nyugalmának biztosítása, a zavaró fizikai tényezők kiiktatása, egy társ - elsősorban az apa - jelenléte, és az újszülött-édesanya együttléte. ${ }^{12}$ Az 1950-es évektől a kórházak újszülött osztályai még úgynevezett „central-system” rendszerben múködtek (az újszülöttet a nap nagy részében elválasztották az édesanyjától, csak a szoptatás ideje alatt találkozhattak, az újszülöttet a csecsemős 
nővérek gondozták, az édesanya dolga csak a szoptatás volt). 1985-től a WHO (Egészségügyi Világszervezet) ajánlásának megfelelően fokozatosan bevezetésre került és a mai napig múködik az úgynevezett „rooming-in” rendszer (az újszülött és az édesanya együttes elhelyezése). 4,5,12,13

A nő-, és családközpontú ellátás folyamatosan elterjedt az országban, általános szemléletté és gyakorlattá vált. Napjainkban, a korábban szülészeti fájdalomcsillapítási forradalomnak számító epidurális analgéziáról (EDA) egyre több szerző is ellentmondásosan vélekedik. Meglátásuk szerint ez ugyan hatékonyan csökkenti a fájdalmat, de például akadályozza a szülő nőket a mozgásban és a testükben zajló folyamatok érzékelésében. ${ }^{14,15}$

Úgy gondoljuk, hogy a hazánkban 1992-ben megjelent „Otthonszülés. Az intézeten kívüli szülés gyakorlati kézikönyve" címú mû megjelenése, ennek tartalma erősen megosztotta akkoriban a hazai szakembereket és a szülőtársadalmat is. ${ }^{16}$ A könyv megjelenését követően majd két évtizeddel, 2011-ben jelent meg az intézeten kívüli szülés szakmai szabályairól, feltételeiről és kizáró okairól szóló rendelet, amely hivatalosan, jogilag is leszabályozott keretek között teszi lehetővé a magyar nők számára az otthonszülést. ${ }^{17} \mathrm{E}$ rendelet megalkotásával a minisztérium és a szülészeti szakma is arra törekedett, hogy a kórházon kívüli szüléseket minél biztonságosabbá, rendezetté és központilag szabályozottá tegyék. ${ }^{18}$

Mind az otthon, mind a kórházakban történő szüléseknél fontos alapelv, nemzetközi ajánlások is megfogalmazzák, hogy a nőket nem szabad egyedül hagyni vajúdásuk és szülésük alatt. Minden nőnek szüksége lenne egy segítőre, aki szülése folyamán végig vele van. ${ }^{8,19}$ Magyarországon az 1997-ben megjelent Egészségügyi törvény tette hivatalosan lehetővé, hogy a szülő nő mellett ott lehessen egy közeli hozzátartozója. ${ }^{20}$

A szülést kísérő partner (rokon, barát, dúla) nem professzionális támogatást nyújt, szerepe inkább abban van, hogy jelen van a szülésnél, elérhető a szülő nő számára. ${ }^{21} \mathrm{Az}$ apa szülés alatti jelenlétének (együttszülés/apás szülés) bizonyítottan számos pozitív hatása van. ${ }^{12,22}$

Véleményünk szerint a szülő-, és családbarát/ családcentrikus szülési nézetek napjainkra a szakemberek által már általánosan elfogadottak, elterjedtek, az ellátás során a szülészeti intézmények jellemzően törekednek ezek megvalósítására, mennyiségi és minőségi változtatásokkal még fokozható lenne a szülők elégedettsége. Az utóbbi években egyre nagyobb figyelem fordítódik az apával kísért szülés mellett az egyéb szüléskísérőkre, elsősorban a dúlákra.

\section{A SZAKMAI TÁMOGATÁS RENDSZERÉNEK VÁLTOZÁSA A SZÜLÉSRE ÉS SZÜLŐSÉGRE FELKÉSZITÉS SORÁN}

A szakmai ellátó rendszer feladata és felelőssége a szülő nők, és a családok minél magasabb szintű felkészítése a szülésre és a szülőségre.

A családcentrikus szemléletmód szerint a szülésfelkészítés célja - a teljesség igénye nélkül - a szüléssel, születéssel kapcsolatos ismeretek megtanítása, annak a szemléletnek az átadása, hogy a nő a szülésének ne csak passzív elszenvedője, hanem aktív résztvevője legyen, az alternatív szülési lehetőségekről történő tájékoztatás, az együttszülés, a szülőszoba megismerése, felkészülés az újszülött ellátására. ${ }^{12}$ Jelenleg több kutatás zajlik a minél sikeresebb betegedukáció elérése céljából. Egyes szakemberek úgy gondolják, hogy a szülés vonatkozásában talán a császármetszés lehetőségére való felkészítés az egyik legfontosabb feladat. A mútét bemutatása videó felvételként tűnik a legeredményesebb megoldásnak, amely nagy részben hozzájárul a betegek félelmének csökkentéséhez a pontos ismeretanyag átadásával. A várandósoktatás épp úgy, mint a betegoktatás, az egyik legfontosabb prevenciós eszköz. Amennyiben tartalmazza a szükséges információkat, úgy nagymértékben növeli a várandós bizalmát és együttmúködési készségét az egészségügyi személyzettel. ${ }^{23,24} \mathrm{~A}$ felkészítésnek ki kell terjednie a speciális szükségletű, mint például a látássérült várandósokra és szülőkre is. ${ }^{25} \mathrm{~A}$ felkészülés egyénés családgondozás keretében, csoportos formában vagy önképzéssel, tanulással történhet. ${ }^{1}$

\section{Egyén- és családgondozás}

A várandós-, és már megszült nők gondozása elsősorban egyéni gondozás formájában történik. ${ }^{20,26,27,28,29} \mathrm{~A}$ várandósgondozás napjainkra olyan komplex egészségügyi szolgáltatássá vált, ami a védőnő, a háziorvos, a szülész-nőgyógyász szakorvos, a várandós választása esetén a 
szülésznő, valamint a várandós együttmúködésén alapul. 2014 óta a várandósgondozást a szülésznőgyógyász szakorvos által megállapított alacsony rizikójú várandósság esetén a szülész-nőgyógyász szakorvos vagy szülésznő, magas rizikójú várandósság esetén kizárólag a szülész-nőgyógyász szakorvos végzi a védőnő és a háziorvos együttmúködésével. ${ }^{27} \mathrm{~A}$ gondozó teambe tartoznak még szükség szerint szakorvosok, gyógytornászok, dietetikusok, ápolók, pszichológusok, szociális munkások, családterapeuták. ${ }^{4,5}$

A szülést követően az édesanyát és a csecsemőt a területi védőnő gondozza tovább, a modern szemléletű gondozásban hangsúlyos a családcentrikus szemlélet. 4,5,27 1993-tól a szociális és 1997-től gyermekvédelmi szféra primer prevenciós programokkal is segítheti a gyermeket váró- és nevelő szülőket, családokat. ${ }^{4,5,7,30}$ Gyermek- és várandós veszélyeztetettség esetén a gyermekvédelem kötelező jelleggel kell, hogy bekapcsolódjon a gondozó munkába. ${ }^{4,5,7}$ A Gyermekvédelmi törvénybe új elemként beemelésre került a várandós anya válsághelyzete definíció, valamint a szociokulturális és egyéb hátrányokkal küzdő, újszülöttet, csecsemőt, és kisgyermeket nevelő szülők számára a fejlődési lemaradást kompenzáló, a szülői kompetenciákat erősítő, az egészséges fejlődést és társadalmi felzárkózást segítő „Biztos kezdet gyerekház" szolgáltatás. ${ }^{7}$ A modern szemléletû felkészítés és gondozás során hangsúlyos a családcentrikus szemlélet és a különböző szakmai területek (egészségügy, gyermekvédelem, szociális terület) együttmúködése. ${ }^{31}$

Szakmai tapasztalatunk szerint az előző generációhoz képest megnövekedett a szülő nőkkel, családokkal foglalkozó, speciális szaktudással rendelkező szakemberek száma, ami pozitív, ugyanakkor az együttmúködés gyakorlásában még erősítésre van szükség.

\section{Csoportos felkészítés}

A '70-es évek végén, a '80-as évek elején Magyarországon jelentős lendületet kaptak a különféle szülésre és szülőségre felkészítő, ingyenesen igénybe vehető, csoportos foglalkozások. Hazánk vonatkozásában 1986-tól beszélhetünk szervezett szülésre felkészítő mozgalomról. ${ }^{4}$ A programok minden várandós részére elérhetőek, általában a kórházak szülészeti osztálya által szervezettek, a szülésre-szülőségre fekszülés alapelemeivel foglalkoznak, gyakran várandóstornával egybekötöttek, és az édesapák számára is nyitottak. Több kórházban az együttszülés előfeltétele az édesapa felkészítésen történő részvétele. ${ }^{4,5}$ Magyarországon sajnos az apák szerepe nem túl jelentős a szülőségre felkészítések során, pedig a jelen társadalmi helyzet ezt igen megkövetelné. A 21. század elején szembesültek a férfiak először az egymásnak ellentmondó elvárásokkal, miszerint a férfi fő feladata az anyagi biztonság megteremtése, mindemellett a nőknek nagy az igénye a családcentrikus hozzállásra. ${ }^{32}$

A szülőségre felkészítő projektek Európában több évtizedes múltra tekintenek vissza, mégsem készült még olyan kutatás, ami ezeket összehasonlította volna. Egy jelenleg folyó kutatásunk, ami egyelőre Svédország, Németország, Franciaország, és Magyarország szülőségre felkészítő programjait vizsgálja, megállapítja, hogy Franciaországban szülészorvos és szülésznő tartja a programokat, a többi országban más szakemberek is. A tanfolyamok tartalmukban, módszereikben eltérőek, a partnertámogatás, a természetes eszközök hangsúlyosabbak, mint hazánkban. A hazai programok számos elemmel bővíthetőek lennének. Tematikájában a svédországi, a szakemberek-résztvevők közötti személyes kapcsolat tekintetében a németországi modell a legsikeresebb. Franciaországban példaértékű a várandósok egészséges életmód- és mozgás oktatása. A nagyszülőkre, a többgyermekes családokra fókuszáló, a párkapcsolatot, az anya-baba kommunikációt fejlesztő programok hasznosak lennének hazánkban is. ${ }^{33}$

\section{Önálló tanulás}

Mindenkinek lehetősége van az önálló tanulással történő felkészülésre is. A szülők szüléssel kapcsolatos ismereteinek bővítését célozta meg a '70-es évek elején megjelenő, „Szülőszoba, tessék belépni!" címú könyv. ${ }^{34} \mathrm{Az}$ előző generáció szülői számára szintén mérföldkövet jelentett az a '80-as évek elején megjelent mú, ami először mutatta be valósághű fényképekkel a méhen belül fejlődő magzatot, a méhen belüli fejlődés állomásait, és először adott reális képet a születés előtti életről, valamint hasznos tanácsokkal látta el a szülőket. ${ }^{35}$ Ugyancsak a szülők ismeretbővítését célozta meg az 
akkoriban napvilágot látott, az élet első tizenkét hónapját bemutató könyv. ${ }^{36}$

Napjainkban számos lehetősége van a szülőknek az önálló tanulásra. A szülők, és az őket felkészítő szakemberek rendelkezésére áll egy speciális, a programozott oktatás elveire épülő, tudományos kutatással igazoltan hatékony modell program, az Aktív szülőségre felkészítő-modell (ASZF). ${ }^{4}$ A program alapját képező könyv azt a célt szolgálja, hogy a szülő́k a családalapításra és gyermekvállalásra tudatosan, aktívan, lehetőleg párban készüljenek, a témában általános alapmúveltséget szerezzenek, és a nagyszülőktől, szülőktől tapasztaltakon túl a megszerzett ismereteiket a saját helyzetükre adaptálva alkalmazzák. 4,5,37,38,39,40,41,42

Könyvből, folyóiratokból, médiából, és napjainkban már a modern világ nyújtotta internetes forrásokból is tájékozódhatnak a szülők. Az internetes források ugyan új tanulási lehetőséget kínálnak a mostani generációnak, a nem megfelelő, szakmaiatlan forrásokból történő tanulás azonban veszélyes lehet, a szakemberek kontrollfunkciója fontos lenne.

A gondozás, a csoportos felkészítés során az önálló tanulásban mind a szülőknek, mind a szakembereknek nagy a felelőssége. Az alternatív lehetőségek közötti választás tudatos, az egyén- és család szükségleteinek megfelelő kell, hogy legyen.

\section{ÖSSZEFOGLALÁS}

Tanulmányunk célja az előző generációhoz képest történő változások, a modern szemléletű szülésre és szülőségre felkészítés bemutatása szakirodalmi kutatómunka és saját szakmai tapasztalatok alapján. Vizsgáltuk a változásokat (1) a családtípusok átalakulása, a család múködéséről alkotott felfogások és szülői feladatok, (2) a szüléssel és szüléstámogatással kapcsolatos modern szemlélet- mód, (3) a szakmai támogatás rendszere vonatkozásában. Mindhárom vizsgált területen jelentős változások történtek az előző generációhoz képest. (1) A családtípusok „színesedtek”: házasságba, élettársi kapcsolatba, egyszülős-, mozaikcsaládba születnek a mai gyermekek. Kialakult a családok múködésmódjával (rendszerszemlélet), és a szülői feladatokkal (családi életciklus mentén történő gondolkodása szülői feladatokról) kapcsolatosan egy új szemléletmód. (2) A szülési félelmet és fájdalmat enyhítő, szüléstámogató, nő- és családcentrikus szülészeti szemlélet (a szülés egy természetes folyamat, a külső fizikai környezet és szüléskísérői támogatás szerepe fontossá vált) és gyakorlat alakult ki. (3) A szakmai munkára vonatkozó új jogszabályok születtek. A szakma támogatási rendszere (gondozás, csoportos felkészítés, önálló tanulás erősítése) mennyiségi (új szakmák megjelenése) és minőségi változáson ment keresztül.

Nagyobb figyelmet kell fordítani arra, hogy a szülők a kezdetektől tisztában legyenek a szülői kötelezettségeikkel és jogaikkal. A szülő- és családcentrikus szülési nézetek napjainkra már általánosan elfogadottak, elterjedtek, de mennyiségi és minőségi változtatásokkal még fokozható lenne a szülők elégedettsége. Az előző generációhoz képest megnövekedett a szülő nőkkel, családokkal foglalkozó, speciális szaktudással rendelkező szakemberek száma, ami pozitív, ugyanakkor az együttmúködés gyakorlásában még erősítésre van szükség. A gondozás, a csoportos felkészítés során, az önálló tanulásban mind a szülőknek, mind a szakembereknek nagy a felelőssége. Az alternatív lehetőségek közötti választás tudatos, az egyén- és család szükségleteinek megfelelő kell, hogy legyen. Az eredményes felkészítés érdekében javasoljuk a szakmai munka általunk is vizsgált hármas szempontrendszer, - (1) család és szülőség, (2) szülés és szüléstámogatás, (3) szakmai támogatás rendszere - szerinti folyamatos felülvizsgálatát. 


\section{HIVATKOZÁSOK}

\footnotetext{
${ }^{1}$ Sedgewick R. The family as a system: a network of relationship. In Psychiatric/Mental Health Nursing: Contemporary readings. D. Van Nostrand Co, Inc, 1978.

${ }^{2}$ Haley J. Uncommon Therapy. N.Y. Co London, Norton, 1973.

${ }^{3}$ Aguilera D, Messick J. Crisis Intervention. Theory and Methodology. St. Louis, MO Mosby, 1998.

${ }^{4}$ Soósné Kiss Zs. Az első gyermeket váró szülők szakmai támogatása. Semmelweis Egyetem Doktori Iskola, Budapest, 2007.

${ }^{5}$ Soósné Kiss Zs. A sikeres családalapítás többé nem titok. Családot alapító párok, őket felkészítő szakemberek kézikönyve. General Press, Budapest, 2014.

${ }^{6}$ Soósné Kiss Zs. A családalapítás útvesztői - az elakadások megelőzése. Egészségfejlesztés. 2014;55(5-6):26-32.

7 1997. évi XXXI. törvény a Gyermekek védelméről és a gyámügyi igazgatásról http://net.jogtar.hu/jr/gen/hjegy doc.cgi?docid=99700031.TV (Elérve: 2018. 06. 06.)

${ }^{8}$ World Health Organisation. Care in normalbirth: a practicalguide. WHO, Geneva, 1996.

${ }^{9}$ International Mother Baby Childbirth Organisation (IMBCO) A Nemzetközi Anya- és Bababarát Szülészeti Ellátásért Szervezet kezdeményezése. 10 lépés, mely az optimális anya- és bababarát szülészeti ellátáshoz vezet. http://imbco.weebly.com/uploads/8/0/2/6/8026178/imbci hungarian.pdf (Elérve: 2018. 06.05.)

10 Leboyer L. A gyöngéd születés. T-Twins, Budapest, 1994.

${ }^{11}$ Armstron P, Feldman S. A születés művészete. Szülés bölcsen, a természet rendje szerint, a tudomány támogatásával. Alternatal, Budapest, 1995.

12 Hagymásy L. Családközpontú szülészet. Signatura, Nyíregyháza, 1994.

${ }^{13}$ WHO/UNICEF közös állásfoglalása, A szoptatás népszerűsítése, támogatása és elősegítése: az anya- és gyermekegészségügyi intzémények különleges szerepe. OCSGYI, NEVI, Budapest, http://szoptatasert.hu/sites/default/files/WHO_UNICEF_ALLASFOGLALAS.pdf (Elérve: 2018. 06.05.)

${ }^{14}$ Hidaka R, Callister LC. Giving Birth With Epidural Analgesia: The Experience of First-Time. Mothers. J Perinat Educ. 2012;21:24-35.

15 Jepsen I, Dauer Keller K. The experience of giving birth with epidural analgesia. Women Birth. 2014;27: 98-103. doi: 10.1016/j.wombi.2014.01.005

${ }^{16}$ Sagov ES,Feinbloom IR, Spindel Peggy et al. Otthonszülés. Az intézeten kívüli szülés gyakorlati kézikönyve. Murus, Budapest, 1992.

${ }^{17}$ 35/2011. (III. 21.) Korm. rendelet az intézeten kívüli szülés szakmai szabályairól, feltételeiről és kizáró okairól http://njt.hu/cgi_bin/njt_doc.cgi?docid=138088.323916 (Elérve: 2018. 06. 06.)

${ }^{18}$ Vincze F, Lipienné Krémer I. Az intézeten kívüli szülés helyzetének és a szülésznők szerepének alakulása hazánkban. Orv Hetil. 2016;157(11):415-23.

${ }^{19}$ National Institute for Care and Health Excellence. Intrapartum care for healthy women and babies, Clinical guideline, 2014. https://www.nice.org.uk/guidance/cg190/resources/intrapartum-care-for-healthy-women-and-babies-pdf35109866447557 (Elérve: 2018.05.05.)

20 1997. évi CLIV. Törvény az egészségügyről https://net.jogtar.hu/jogszabaly?docid=99700154.TV (Elérve: 2018.06.05.)

${ }^{21}$ Hodnett ED. Nursing support of the laboring woman. J Obstet Gynecol Neonatal Nurs. 1996;25(3):257-64.

${ }^{22}$ Soltész A, Rigó A, Pápay N. Az együttszülés jelentősége. In: Pápay N, Rigó A (editor). Reproduktív egészségpszichológia. ELTE Eötvös Kiadó, Budapest, 2015. pp353-70.

${ }^{23}$ Sobel G, Langmár Z, Tömösváry Z, et al. Hogyan javítható a páciensek tájékozottsága a végzett

mútétek kapcsán? - Megfontolások a mindennapi gyakorlat számára. Orv Hetil. 2010;151(20):822-7.

doi: 10.1556/OH.2010.28843 https://doi.org/10.1556/OH.2010.28843 (Elérve: 2018. 06. 08.)

${ }^{24}$ Tóth T, Dinya E. A személyre szabott betegoktatás lehetőségei. Orv Hetil. 2013;154(11):403-8.

doi: 10.1556/OH.2013.29564, https://doi.org/10.1556/OH.2013.29564 (Elérve: 2018. 06. 07.)

${ }^{25}$ Tolnayné Csattos Márta: A csecsemőgondozás speciális technikái. Tájékoztató kiadvány látássérült szülők, nagyszülők, rokonok, ismerősök, barátok és őket segítő szakemberek számára. Vakok Állami Intézete, Budapest, 2011.

${ }^{26}$ 49/2004. (V. 21.) ESZCSM rendelet a területi védőnői ellátásról http://njt.hu/cgi_bin/njt_doc.cgi?do-

cid=84519.289052 (Elérve: 2018. 06. 06.)

${ }^{27}$ 26/2014. (IV. 8.) EMMI rendelet a várandósgondozásról http://njt.hu/cgi_bin/njt_doc.cgi?docid=168562.318326

(Elérve: 2018. 06. 06.)

28 2015. évi CXXIII. törvény az egészségügyi alapellátásról

http://njt.hu/cgi_bin/njt_doc.cgi?docid=176686.323167 (Elérve: 2018. 06. 06.)
} 
${ }^{29}$ NEFMI szakmai protokoll a kórházi védőnői feladatokról a szülészeti és újszülött ellátásban https://kollegium.aeek.hu/conf/upload/oldiranyelvek/GYERM-ALAP_korhazi\%20vedonoi\%20feladatokrol\%20a\%20szuleszeti\%20es\%20ujszulott\%20ellatasban_mod0_v0.pdf (Elérve: 2018. 06. 06.)

30 1993. évi III. Törvény a szociális igazgatásról és ellátásról

https://net.jogtar.hu/jogszabaly?docid=99300003.TV (Elérve: 2018.06 .07$.

${ }^{31}$ Soósné Kiss Zs. Egészségügyi és szociális szakemberek közös felelőssége az első gyermeket váró szülők támogatásában. Nővér. 2002;15(5):7-10.

32 Takács, J. Aktívan törődő apák Magyarországon. Szociológiai Szemle. 2017;27(3):104-26.

33 Prajda DB, Péter M, Gadó K. et al. Javaslatok a hazai szülőségre felkészítésre vonatkozóan, nemzetközi projektek alapján. Ártó-védő Társadalom Konferencia absztrakt könyv, SE ETK, Budapest 2018. p:27.

${ }^{34}$ Hirschler I. Szülőszoba, tessék belépni! Medicina, Budapest, 1974.

${ }^{35}$ Nilsson L, Furuhjilm M, Ingelman-Sundberg A, et al. Fényképek a születés előtti életről és hasznos tanácsok szülőknek. Medicina, Budapest, 1981.

${ }^{36}$ Caplan F. Az élet első tizenkét hónapja. Medicina, Budapest, 1986.

${ }^{37}$ Soósné Kiss Zs. Programozott oktatás és alkalmazási lehetősége a szülőségre felkészítésben. Egészségnevelés. 2002;43(6):276-9.

38 Soósné Kiss Zs. Spezielle Unterstützung der Eltern, die ihre Kinder in Ungarnbekommen. Pflegezeitschrift. 2004;57(7):476-80

39 Soósné Kiss Zs. Egy speciális szülőségre felkészítő modell módszertani elemeinek bemutatása. Egészségfejlesztés. 2006;47(3):11-4.

40 Soósné Kiss Zs. Első gyermeket váró szülők felkészültsége az „Aktív szülőségre felkészülés modellhez kapcsolódó kutatás tükrében. Háziorvos Továbbképző Szemle. 2007;12(3):228-32.

${ }^{41}$ Soósné Kiss Zs. A szülőségre felkészülés egy új lehetősége, az "Aktív szülőségrefelkészülés (ASZF)"-modell. Védőnő. 2007;17(2):3-7.

${ }^{42}$ Soósné Kiss Zs. Ergebnisse des Programms „Vorbereitung auf aktive Elternschaft”: Werdende Eltern erfolgreich schulen. Pflegezeitschrift. 2009;62(5):268-9. 